\title{
RELIGIÃO, CIÊNCIA E CAPITALISMO: SUJEITO MASSIFICADO, OBJETO PADRÃO E MEDIDA COMUM PARA O GOZO
}

Heloisa Helena Marcon*

Heloisa Helena Marcon Universidade de São Paulo (USP), Doutoranda do Instituto de Psicologia, São Paulo/SP, Brasil.

* Université Paris VII Denis Diderot, Paris, France

Bolsista da Capes PDSE, Paris, França. (Proc. n. BEX0403/15-6)
RESUMO: O presente artigo discute, desde a psicanálise, de que maneira os discursos da religião, da ciência e do capitalismo ao produzirem a massificação dos sujeitos através da oferta de um sentido, de um saber e de um objeto padrão colocados como medida comum para o gozo acabam excluindo não apenas a singularidade do sujeito, mas, cada vez mais, suas chances inventivas diante do desamparo e do mal-estar, condições estruturais e estruturantes da vida humana.

Palavras-chave: religião; ciência; capitalismo.

ABSTRACT: Religion, science and capitalism: massified individual, standard object and common measure for enjoyment. This article discusses, from psychoanalysis, how religion, science and capitalism discourses producing massification of the individuals through the offer of a standardized meaning, knowledge and object, set as a common measure for enjoyment end up excluding not only the singularity of the individual but also their inventive chances before helplessness and uneasiness, structural and structuring conditions of human life.

Keywords: religion; science; capitalism. 
Infelizmente, vejo esse registro sem influência sobre uma impotência que só faz crescer à medida que temos mais oportunidade de operar os ditos efeitos. Impotência cada vez maior do homem de se reunir ao seu próprio desejo, impotência que chega a fazer com que ele perca a deflagração carnal. Ainda que esta permaneça disponível, esse homem não sabe mais achar objeto para seu desejo, não encontrando senão infelicidade em sua busca, a qual ele vive numa angústia que restringe cada vez mais o que poderíamos chamar de sua chance inventiva.

(Lacan, 1960/2005, p. 18)

\section{O DESAMPARO FUNDAMENTAL DO SUJEITO}

A partir de Freud (1930/1980), no clássico O mal-estar na civilização, sabe-se que foi devido à fraqueza e ao desamparo do ser humano diante das forças impiedosas da natureza e das dificuldades de relação com os outros homens que se criou a cultura/civilização. Assim, “(...) a palavra civilização descreve a soma integral das realizações e regulamentos que distingue nossas vidas das de nossos antepassados animais (...)” (FREUD, 1930/1980, p. 109).

No entanto, uma vez que as tentativas de controle da natureza se mostraram falhas, o homem seguiu sentindo-se em desamparo e, por isso, inventou a ilusão de uma Providência benevolente (Deus Pai) que velava por todos. Desse estado de coisas, nasceram as ideias religiosas, sistemas de crenças quefornecem a ilusão de proteção e segurança, como podemos acompanhar em Freud:

A derivação das necessidades religiosas, a partir do desamparo do bebê e do anseio pelo pai que aquela necessidade desperta, parece-me incontrovertível, desde que, em particular, o sentimento não seja simplesmente prolongado a partir dos dias da infância, mas permanentemente sustentado pelo medo do poder superior do Destino. Não consigo pensar em nenhuma necessidade da infância tão intensa quanto a da proteção de um pai. (...) A origem da atitude religiosa pode ser remontada, em linhas muito claras, até o sentimento de desamparo infantil. (FREUD, 1930/1980, p. 90)

O desamparo aparece na origem da civilização, mas ele segue mesmo depois de estarmos em comunidade como necessidade de proteção do Destino, o que Freud denomina de sentimento de desamparo infantil. No entanto, como traz Costa Pereira (2008), tal desamparo não se resume, para Freud, num sentimento exclusivo do pequeno ser humano quando é ainda incapaz de sobreviver por seus próprios meios — o que Lacan (1949/1998) vai chamar de fetalização em O estádio do espelho como formador da função do eu, mas de uma “(...) dimensão fundamental da vida psíquica que indica os limites e as condições de possibilidade do próprio processo de simbolização” (COSTA PEREIRA, 2008, p. 127). 
Dessa forma, a religião vem tentar dar conta de algo que é impossível de representar completamente e que, portanto, é, em termos lacanianos, do registro do real: o desamparo humano. E como a religião faz isso e quais efeitos produz no sujeito?

Em O futuro de uma ilusão, Freud (1927/1980) está muito menos interessado nas fontes do sentimento religioso do que naquilo que o homem entende como sua religião: o sistema de doutrinas e promessas que lhe explica os enigmas do mundo com perfeição invejável e lhe garante uma Providência cuidadosa que velará por sua vida e o compensará numa existência futura de quaisquer frustrações experimentadas na vida terrena. Como vimosem O mal-estar na civilização, essa Providência é imaginada pelo homem comum sob a figura de um pai ilimitadamente engrandecido, na medida em que “Tudo é tão patentemente infantil, tão estranho à realidade, que, para qualquer pessoa que manifeste uma atitude amistosa em relação à humanidade, é penoso pensar que a grande maioria dos mortais nunca será capaz de superar essa visão de vida” (FREUD, 1930/1980, p. 92).

Trata-se, portanto, de uma visão de vida ou visão de mundo que explica aos homens com perfeição os enigmas do mesmoe, mais que isso, lhes promete felicidade, ainda que numa vida futura, depois da morte. Nesse sentido, Freud (1930/1980) classifica a operação efetuada pelo discurso religiosocomo uma tentativa de obter uma certeza de felicidade e uma proteção contra o sofrimentoa partir de um remodelamento delirante da realidade. "As religiões da humanidade devem ser classificadas entre os delírios de massa desse tipo. É desnecessário dizer que todo aquele que partilha um delírio, jamais o reconhece como tal" (FREUD, 1930/1980, p. 100).

Mesmo sendo um delírio de massa, Lacan (1974/2005) sublinha o poder da religião, na medida em que ela é capaz de dar um sentido a realmente qualquer coisa.

Desde o começo, tudo que é religião consiste em dar um sentido às coisas que outrora eram as coisas naturais. Não é porque as coisas vão se tornar menos naturais, graças ao real, que se vai parar de secretar o sentido. E a religião vai dar um sentido às experiências mais curiosas, aquelas pelas quais os próprios cientistas começam a sentir uma ponta de angústia. A religião vai encontrar para isso sentidos truculentos. É só ver o andar da carruagem, como eles estão se atualizando. (LACAN, 1974/2005, p. 66)

A religião, portanto, produz um sentido que é compartilhado por muitos. Um sentido para o que, antes dela, era lido pelos homens como as coisas da natureza. Importante colocação de Lacan de que, não importa o que aconteça com o real, não pararemos de tentar lhe dar sentidos. Nesse contexto, as coi- 
sas da natureza não andam conforme os desejos do homem. Elas podem ser assombrosas, pois funcionam à nossa revelia e, nesse sentido, não funcionam. Para Lacan (1974/2005), o real é o que não funciona, em oposição às coisas do mundo, que funcionam. Por isso, ele vai afirmar que "A religião é feita para isso, para curar os homens, isto é, para que não percebam o que não funciona” (LACAN, 1974/2005, p. 72). O real de que ela trata, segundo Askofaré (2009), é o real da origem, o real do pai; em última instância, o real do tempo e da morte.

Nesse caminho, como atenta Lacan (1966/1998), o religioso entrega a Deus a incumbência da causa - a causa de tudo, inclusive de seu próprio desejo e, precisamente nisso, corta seu próprio acesso à verdade, instalando-a num status de culpa. Por isso, Di Ciaccia (2005) afirma que o discurso religioso se propõe como mediador da relação de cada sujeito com seu desejo e com seu gozo, uma vez que ele barra de modo muito particular o corpo, o corpo que deseja, o corpo que goza. O desejo deve ser sublimado para além da carne e o gozo é prometido, mas para o corpo eterno, após a morte. A religião promete uma certeza de felicidade e uma proteção contra o sofrimento, na medida em que garante sentido para tudo.

A religião restringe esse jogo de escolha e adaptação, desde que impõe igualmente a todos o seu próprio caminho para a aquisição da felicidade e da proteção contra o sofrimento. Sua técnica consiste em depreciar o valor da vida e deformar o quadro do mundo real de maneira delirante - maneira que pressupõe uma intimidação da inteligência. A esse preço, por fixá-las à força num estado de infantilismo psicológico e por arrastá-las a um delírio de massa, a religião consegue poupar a muitas pessoas uma neurose individual. Dificilmente, porém, algo mais. Existem, como dissemos, muitos caminhos que podem levar à felicidade passível de ser atingida pelos homens, mas nenhum que o faça com toda segurança. Mesmo a religião não consegue manter sua promessa. (FREUD, 1930/1980, p. 104)

É preciso sublinhar que a restrição efetuada pela religião, conforme apontado por Freud (1930/1980), é a da imposição de um único e igual caminho para todos no acesso à felicidade e proteção contra o sofrimento. Nesse sentido, ela visa poupar o sujeito da dimensão do conflito e da dúvida, na medida em que está ancorada em uma construção delirante compartilhada. A segurança prometida pela religião restringe para o sujeito a possibilidade de construir uma solução particular frente ao desamparo, o que é possível aos homens, mas que, de antemão, não está garantida. Dito de outro modo, a religião, ao pretender assegurar proteção e felicidade, dirige o pensamento dos homens pela imposição de preceitos autoritários, com um absolutismo incomparável, que persiste até os dias de hoje (BERNARDES, 2007). 


\section{O SENTIMENTO DE CULPA E A AGRESSIVIDADE}

Para Freud (1930/1980), a agressividade constitui no homem uma disposição original e auto-subsistente, sendo ela o maior impedimento à cultura/civilização. Nesse sentido, o autor aponta que os meios que a cultura/civilização utiliza para inibir a agressividade consistem na sua introjeção e internalização, quando a mesma é enviada de volta para o lugar de onde proveio, o próprio ego. A agressividade é assumida por uma parte do ego que se coloca, como superego, contra o resto do egoe que, sob a forma de consciência, está pronta para pôr em ação contra o ego a mesma agressividade que teria colocado sobre outros indivíduos a ele estranhos. Portanto, o outro é sentido como uma ameaça, conforme chamam a atenção Reino e Endo (2011).

Para Freud, o surgimento do superego dá origem ao sentimento de culpa. Enquanto a autoridade provém de uma autoridade exterior e o sujeito se submete a ela por medo da perda do amor e consequente perda da proteção, "uma grande mudança só se realiza quando a autoridade é internalizada através do estabelecimento de um superego" (FREUD, 1930/1980, p. 148).

O sentimento de culpa surge, então, com o superego para dar algum destino à agressividade constitutiva. Ele tem, portanto, uma função importante na manutenção da cultura/civilização. Como aponta Freud: “As religiões, pelo menos, nunca desprezaram o papel desempenhado na civilização pelo sentimento de culpa. Ademais (...), elas alegam redimir a humanidade desse sentimento de culpa, a que chamam de pecado" (FREUD, 1930/1980, p. 160).

E de que maneira as religiões alegam redimir a humanidade do sentimento de culpa - o pecado? Usando da agressividade constitutiva e dirigindo-a, como o faz o superego em direção ao ego, como se ele fosse os outros indivíduos a ele estranhos. Para tanto, a formação de grupo é fundamental, como aponta Freud:

Evidentemente, não é fácil aos homens abandonar a satisfação dessa inclinação para a agressão. Sem ela, eles não se sentem confortáveis. A vantagem que um grupo cultural, comparativamente pequeno, oferece, concedendo a esse instinto um escoadouro sob a forma de hostilidade contra intrusos, não é nada desprezível. É sempre possível unir um considerável número de pessoas no amor enquanto sobrarem outras pessoas para receberem as manifestações de sua agressividade. Dei a esses fenômenos o nome de 'narcisismo das pequenas diferenças'. (FREUD, 1930/1980, p. 136)

Dessa forma, constituindo um grupo, como aparece na religião sob a forma dos "filhos de Deus” ou “irmãos em fé”, ao sujeito é permitido direcionar sua agressividade para os que não são "filhos de Deus”. “Afinal, os integrantes de 
uma massa supõem-se todos irmãos indiferenciados, como se tivessem a mesma forma, uni-form-izados” (REINO; ENDO, 2011, p. 21). E, assim, o outro, a alteridade, pode ser um dos destinos da agressividade.

\section{PSICANÁLISE E CIÊNCIA}

Desde seus primórdios, a ciência moderna se apresenta com a intenção de dar alguma ordem de funcionamento ao real da natureza, como sabemos desde Freud, fonte constante de mal-estar. Conforme Askofaré (2009), desde que rompeu com a epistheme grega, a ciência moderna é o exame dessa natureza e tornou-se tecnociência. Constitui saber e conhecimento desta mesma natureza para melhor submetê-la e dominá-la. Vontade de saber e vontade de domínio se tornam, por assim dizer, homotéticas nesta figura do saber que é a ciência moderna. Nesse contexto, "aquilo que a religião pretende, prendendo com a verdade do sentido, a ciência procura mediante o saber”, indica Rebollo (2010, p. 6). Assim, enquanto a religião busca dar sentido ao desamparo e ao mal-estar através de significações do tipo "Você está passando por isso porque Deus quer que seja assim, é o seu Destino”, a ciência explica que “isso” está acontecendo devido a um desarranjo neurológico e bioquímico em seu cérebro.

Conforme propõe Lacan (1974/2005), a ciência nos dá acesso ao real real, ao verdadeiro real a realidade física que ele vai dizer ser plena, totalmente inumana.

Para Lacan (1966/1998), a ciência moderna inaugura uma nova posição de sujeito e a reforça. O sujeito, de acordo com Lacan (1966/1998), é tomado numa divisão constitutiva entre o saber e a verdade. Essa relação com o saber preserva, desde Descartes, o nome de cogito. Lacan (1966/1998) também afirma que o sujeito sobre quem operamos na psicanálise só pode ser o sujeito da ciência, pois, desde seu advento, nada mais temos para conjugar saber e verdade senão esse sujeito.

Mas o que Lacan pode querer dizer com isso - que o sujeito sobre quem operamosna psicanálise só pode ser o sujeito da ciência? Que o sujeito da consciência - esse que pensa e duvida, como demonstra Descartes no seu cogito e o sujeito do inconsciente - esse a quem temos acesso a partir das manifestações do inconsciente tal como desde Freud são a mesma coisa?

No artigo intitulado A subjetividade no trabalho com saúde mental (2007), trabalhei justamente a diferença entre essas concepções de sujeito e os efeitos na clínica. O ponto de partida foi tencionar a concepção de sujeito hegemônica do século XXI, de tal modo arraigada e "naturalizada" que se chegou a perder de vista que se trata de uma construção advinda de um processo histórico e social. Esta concepção de sujeito não é natural, ela não é algo da "natureza do homem” (o que quer que isso possa querer dizer) ou inata, isto é, ela não é da ordem de um dado da natureza e, por isso, determinadamente óbvia e necessária, apesar 
de toda a ciência atual, que se constrói a partir desta concepção, se esforçar para sustentá-la com esse suposto estatuto de natureza.

A noção de sujeito da ciência moderna éa que foi proposta por Descartes no seu Discurso do método. Do fato de Descartes duvidar da verdade das outras coisas dúvida hiperbólica ele encontrou a verdade de que existia, e então reconheceu que: “(...) eu era uma substância, cuja única essência ou natureza é pensar (...)" (DESCARTES, 1996, p. 38). A célebre formulação, cogito ergo sum tem diferentes interpretações, portanto também diferentes traduções. "Penso, logo sou” e "Penso, logo existo" são as mais conhecidas. A questão do estatuto do articulador "logo", presente nas proposições recém referidas, é o que esclarece do que se trata para Descartes, uma vez que não se trata de uma proposição dedutiva, que é justo o que o "logo" leva imediatamente a pensar. Assim, não é porque penso que sou ou existo, mas, antes, que o estatuto do meu ser ou do meu existir é todo dado pelo pensar. Por isso, Vallejo e Magalhães afirmam que o cogito ergo sum deve ser tomado como uma proposição de natureza analítica "na qual o que se formula no predicado tem que estar incluído no sujeito do enunciado" (1981, p. 15). Dessa forma, o pensar envolve em si mesmo o ser ou existir, de modo que não haveria nada da ordem do ser ou do existir do sujeito fora desse pensar.

É justamente na pura reflexividade de Descartes que se postula uma perfeita coincidência do sujeito consigo mesmo e brota a concepção do sujeito como agente absoluto, ponto de partida da totalidade de seus atos e plenamente coincidente consigo mesmo. O sujeito cartesiano não é marcado por nenhuma ruptura, há uma perfeita possibilidade de que o sujeito coincida consigo mesmo na reflexão. As duas teses, a do sujeito agente e a do sujeito adequado, são básicas na colocação tradicional da noção de sujeito. (VALLEJO; MAGALHÃES, 1981, p. 15)

Descartes (1996), dessa forma, propõe que nossa existência é dada no registro da consciência, no registro do pensamento, da reflexão. Desse modo, há uma coincidência entre eu, sujeito, consciência e pensamento, pois o sujeito se identifica com o cogito e, através deste, se identifica com a consciência. Trata-se, portanto, de um sujeito agente, centrado no cogito.

Entretanto, para Lacan (1954-1955/1985), é a partir de Freud que se produz a irrupção de uma nova perspectiva que revoluciona a concepção de sujeito, mostrando justamente que o mesmonão se confunde com o eu e a consciência.

Na teoria freudiana, o sujeito é um sujeito fendido, subordinado a uma outra cena, a um outro lugar além dele — o inconsciente — destinado a uma não-convergência consigo mesmo, a "uma impossibilidade de nomeação do sujeito como área completa ou adequada” (VALLEJO; MAGALHÃES, 1981, p. 17), uma vez que o sujeito é determinado a partir de uma ordem inconsciente. É esse 
descentramento de que o sujeito não é igual à consciência, mas é determinado a partir do inconsciente que permite a Lacan nomear a descoberta freudiana do inconsciente de revolução copernicana, pois, de fato, descentra, tira do centro, o sujeito, até então idêntico ao eu ou à consciência. De acordo com Lacan (19541955/1985), tudo o que Freud escreveu visava restabelecer a perspectiva exata da excentricidade do sujeito com relação ao eu.

Nesse sentido, o que Lacan assinala ao afirmar que o sujeito sobre quem operamos na psicanálise é o mesmo da ciência e que a psicanálise não existiria sem que a ciência moderna a precedesse logicamente é que a psicanálise consiste em uma prática e uma teoria que serve para tratar dos fatos que a ciência excluiu para poder se constituir — o inconsciente e suas formações (LAPEYRE; SAURET, 2008).

E por que a ciência precisou excluir o sujeito do inconsciente para poder constituir-se? De acordo com Costa (2011), a ciência excluiu o sujeito para produzir os seus sistemas, na tentativade produzir um saber objetivo. Ou seja, excluiu o que é próprio do sujeito enquanto sujeito singular, na medida em que nome, sobrenome, relação com o sexo e com o gozo não produzem um saber objetivo que pode servir a todos os sujeitos - objetivo desta ciência que, como vimos anteriormente, se tornou tecnociência (LAPEYRE e SAURET, 2008).

Por outro lado, as intervenções do psicanalista permitem uma abertura tal que o que surge do encontro da intervenção de um psicanalista com um paciente escapa a toda decodificação pontuável a partir de uma grade de saber prévio. Por isso, em psicanálise, não pode haver estatísticas sobre os sintomas, na medida em que o sintoma não tem valor de signo. Na psicanálise, o sintoma tem valor linguageiro, valor metafórico a decodificar. No entanto, é uma decodificação relativa somente e exclusivamente à função que tem para o sujeito que ali se compromete. De modo que o "resultado" obtido só tem sentido diante das apostas feitas naquele percurso, e não em relação a uma média, como coloca Szpirko (1995).

Assim, a condição para que a ciência produza um saber objetivo é excluir o sujeito enquanto sujeito singular.

Mais grave, uma ciência que apaga singularidades priva os sujeitos do apoio do sintoma; ela faz deles indivíduos equivalentes uns aos outros, capazes de serem reunidos não somente numa mesma amostra, mas numa mesma massa, de mesma natureza que aquela que se observam todos os totalitarismos, conforme Arendt (As origens do totalitarismo). (LAPEYRE; SAURET, 2008, p. 302)

É nesse contexto que Hannah Arendt (2014) afirma que a estatística tornou-se o principal instrumento técnico da sociedade de massas, constituindo a ciência 
social por excelência! Para tornar-se uma ciência, a medicina, por exemplo, precisou se constituir como campo de saber com uma lógica própria. Para isso, privilegiou certos fatos e impôs um certo olhar sobre eles, excluindo todos os outros fatos que não têm como serem articulados na sua grade lógica para que ela tenha alguma coerência. Então, se antes a religião anunciava a igualdade dos sujeitosna morte, agora, a medicina anuncia essa igualdade na doença. "Para aceder à igualdade, outrora bastava estar morto. É suficiente agora estar doente" (CLAVREUL, 1983, p. 32).

Para produzir um saber científico, portanto, objetivo, o discurso médico precisou produzir a igualdade e a equivalência dentro do seu quadro lógico, de modo que ele possa ser enunciado por qualquer um sobre qualquer pessoa; ou seja, de modo que os sujeitos das ações somem. Do mal-estar que provém do fato de que não é suportável ser qualquer um, a medicina nada tem a dizer. Para constituir-se como saber científico, o discurso médico precisou, portanto, eliminar “(...) qualquer outro discurso, e consequentemente, o do próprio doente (...)” (CLAVREUL, 1983, p. 84), afastando inúmeros elementos que têm interesse em si mesmo, mas que não cabem na grade de saber do discurso médico. São elementos “singularmente insistentes” (CLAVREUL, 1983), uma vez que os doentes os apresentam continuamente aos médicos. Mas esses elementos são verdadeiramente "não fatos" para a medicina, na medida em que dizem respeitoao que não entra nesta grade lógica, ao que alguém pode produzir como fala quando ali está como sujeitosingular, logo, destacado da massa. É quando o paciente cansa o médico, pois, para funcionar a relação ao modo “científico”, é preciso que o doente não fale. O sofrimento

(...) existe para o médico apenas como um sintoma, isto é, na medida em que é formulável nos significantes constituintes de uma síndrome que caiba na nosologia. No fundo, o doente não fala enquanto tal ao médico: ele fala dele como falaria de um outro, e o interesse do que ele diz se deve somente ao fato de que ele é um observador privilegiado de sua doença. O que ele diz é sempre da ordem desse “33” que ele deve repetir em voz alta para que o médico, na ausculta pulmonar, avalie a "pectoriloquia". Do que é dito o médico só retém o que ressoa no discurso médico. Pouco importa para ele se o doente teve sua primeira dor precordial no dia da morte de seu irmão! (CLAVREUL, 1983, p.157-158)

Nesse contexto, o sujeito acaba sendo excluído da grade de saber objetivo do discurso médico, podendo apenas aparecer como "corpo" nessa massa estatística. Dessa forma, assim como na religião, a ciência também produz um efeito de massa. Entretanto, sem colocar os sujeitos como os "filhos de deus" em oposição aos não "filhos de deus", mas tornando todos "naturalmente" equivalentes 
uns aos outros, numa mesma massa uniforme, portanto, padrão. Ou seja, assim como a religião, a ciência também exclui o sujeito singular com seu sintoma. De maneira que

(...) o problema se torna complexo no momento em que a própria ciência passa a ocupar o lugar do Sujeito-suposto-Saber. Desse modo, ela tenta ocupar um lugar digno de todo respeito no discurso religioso. Assim, por um lado, a ciência abala e enfraquece o Sujeito-suposto-Saber da religião, mas, por outro, a própria religião utiliza aquilo que se apresenta como discurso científico em prol dos seus próprios fins. (DI CIACCIA, 2005, s/p.)

O exemplo dado pelo autor acerca do uso da ciência por parte da religião diz respeito à justificação científica usada pela igreja para sua posição contra o aborto. Esta justificativa não é dada a partir das Sagradas Escrituras, mas a partir das afirmações de um médico da Universidade de Louvainproferidas no século XVII. Esta ajuda solicitada pela religião para a ciência tem por objetivo, como aponta Di Ciaccia (2005), (re)estabelecer um acordo entre o sentido e o real, entre religião e ciência, no intuito de que eles possam caminhar tranquilamente de mãos dadas, o que já havia sido assinalado por Lacan (1960/2005).

Desta forma, se, por um lado, encontramos a religião buscando na ciência argumentos para justificar suas posições, por outro, parece que a ciência vem delegando à religião isso que diz respeito ao que se relaciona com a verdade, e não com o saber. Lacan (1966/1998) diz que o que está em causa na ciência é a estrutura de suas relações da verdade como causa, mas assinala que “(...) da verdade como causa, ela [a ciência] não quer-saber-nada”, (LACAN, 1966/1998, p. 889), delegando-a, portanto, para a religião. Da verdade de que precisou excluir o sujeito enquanto singular para poder se constituir do modo como se constituiu, por exemplo, (isto é, da sua causa), a ciência não quer saber nada.

À vista disso, assim como vimos que a religião, ao sustentar a promessa de assegurar proteção e felicidade, dirige o pensamento dos homens pela imposição de preceitos de caráter autoritários, do mesmo modo, a ciência não pode se furtar ao fato de que, das suas aplicações, se derivem "normas e orientações quanto à conduta de vida” (FREUD, 1933/1980, p. 197), as quais, muitas vezes, são coincidentes com as da religião. As medidas sanitaristas e higienistas o mostram bem, como nos lembra Bernardes (2007). Os imperativos relativos à saúde, à alimentação e à higiene são derivados das descobertas científicas; e cuidar bem do corpo que Deus nos deu, mas com parcimônia, isto é, sem excessos (é a ciência que determina esta justa medida para todos), se tornou uma obrigação de todos.

Religião e ciência, pela via do sentido e pela via do saber, respectivamente, visam, portanto, obturar o mal-estar. Apesar de Lacan afirmar que o caminho 
científico é o único que dá acesso ao real real - o real físico — ele também nos diz: "Mas o real ao qual acessamos com pequenas fórmulas, o verdadeiro real, é coisa totalmente diferente. Até o presente, só temos gadgets como resultado disso" (LACAN, 1974/2005, p. 77).Ou seja, os produtos da ciência, os gadgets, não são o real da ciência, mas guardam uma deficiência estrutural na medida em quetudo que o homem produz sempre cai sob a marca da falta.

\section{PSICANÁLISE E CAPITALISMO}

Lacan (1974/2005), em seu Discurso aos Católicos, procurou sublinhar que, para a falta de garantias, falta de segurança, falta de proteção, falta de felicidade plena, falta de representatividade total do mundo, isto é, para isso que é próprio do falasser, o sujeito está sempre tentando encontrar uma solução: religião, ciência, religião com ciência e ciência com religião (Cientologia, por exemplo). A última novidade, não tão nova assim, pois data do século passado, é a ciência ter contraído núpcias com o capitalismo e, assim, oferecer o objeto sob medida para cada sujeito, dando a pensar, obviamente, que se conseguem nos dar o objeto de que precisamos é porque teriam também um saber específico ou sob medida sobre cada um de nós. Entretanto, paradoxalmente, cada vez mais "os indivíduos se descobrem em uma condição em que pensam, sentem, fazem e amam exatamente as mesmas coisas nas mesmas horas, em porções do espaço estritamente equivalentes" (LACAN, 1950/1998, p. 146).

De acordo com Lacan, (1969-1970/1992), esses objetos são latusas, pequenos objetos a feitos para causar o desejo. Gerados e governados pela ciência, esses objetos são consumidos freneticamente, colocando o sujeito a serviço dos objetos e escravo das produções do mercado.

Dessa forma, é através da ciência que o capitalismo vai criar esse objeto que, ancorado na promessa de ser sob medida, massifica os sujeitos. Dito de outro modo; “O objeto produzido em série — todos iguais — pelo interesse capitalista trará a moldura na qual o sujeito deve adaptar-se: para um objeto padrão, um sujeito massificado" (VOLTOLINI, 2011, p. 270).

O sujeito massificado, diga-se de passagem, sacrificado, é fruto de um discurso que, como Lacan (1966) já assinalou em relação à ciência, opera no registro da comunicação, reduzindo o sujeito à condição de receptor de signos estereotipados transmitidos pelos meios de comunicação de massa. Esse sujeito adormecido é facilmente capturável pelo mercado, pois está à espera dos objetos que lhe são oferecidos para usufruto de seu gozo que, nesse mercado, passa a ser também o mesmo para todos os sujeitos. Com a ajuda da ciência, o capitalismo produz um sujeito massificado, um objeto padrão e uma medida comum para o gozo. 
Entretanto, não basta criar mercadorias, é preciso gerar demandas a partir dessas relações significantes que produzem os signos estereotipados da publicidade. As demandas são produzidas a partir da sedução que objetivacativar o consumidor e aprisioná-lo, se possível interminavelmente, na necessidade de um objeto específico, feito para ele, sob medida.

De acordo com Haug (1997), a aparência dos objetos de consumo na qual caímos é como um espelho, onde o desejo se vê e se reconhece como objetivo. Graças a um engodo abominável são produzidas sequências intermináveis de imagens que se apoderam do sujeito atuando como espelhos, com empatia, observando seu íntimo, trazendo à tona os seus segredos mais inconfessáveis.

Nessas imagens evidenciam-se às pessoas os lados sempre insatisfeitos de seu ser. A aparência oferece-se como se anunciasse a satisfação; ela descobre alguém, lê os desejos em seus olhos e mostra-os na superfície da mercadoria. Ao interpretar as pessoas, a aparência que envolve a mercadoria mune-a com uma linguagem capaz de interpretar a si mesma e ao mundo. Logo não existirá mais nenhuma outra linguagem, a não ser aquela transmitida pelas mercadorias. (HAUG, 1997, p. 77)

Nesse sentido, o capitalista tem a importante tarefa de propor modos de sedução. Nessa sedução, utiliza a própria dinâmica do desejo para suprimi-la, instaurando o reino da necessidade. Na sedução, está em cena o brilho da miragem do objeto perdido (fundo de ausência do objeto no campo do desejo) tentando dar-lhe uma outra consistência sustentada na oferta e na promessa do capitalista, que “(...) entra, então, com um novo objeto, que reimpulsiona a crença em um objeto que pode completar o vazio da falta” (VOLTOLINI, 2011, p. 271).

Trata-se de objetos que moldam o gozo às necessidades forjadas pela publicidade e que, alimentadas pela ciência, descortinam para o homem contemporâneo, reduzido à condição de sujeito massificado e objeto consumido pela lógica capitalista, um admirável mundo novo. Conforme Ferreira (2010), um mundo em que os objetos ofertados pelas técnicas advindas da ciência visam mascarar, simultaneamente, o mal-estar da condição humana e o mal-estar da civilização.

Os novos objetos, embalados em pacotes estandardizados, moldam o gozo às necessidades forjadas pela publicidade e alimentadas pela ciência. Assim se descortina para o homem contemporâneo, reduzido à condição de objeto e jogado na mais profunda solidão, um admirável mundo novo. As máquinas oferecem um mosaico deinformações que, para se ter acesso, basta, sem sair de casa, apertar um botão. Os discursos dominantes exigem que todos se tornem um self made man. A indústria farmacêutica enriquece nos rastros da ciência, oferecendo remédios que prometem 
a cura do mal-estar e substituem o dizer pela ação de engolir uma pílula ou tomar uma injeção. (FERREIRA, 2010, p. 424)

Objetos que sustentam a promessa de não apenas aliviar o mal-estar, mas de levar o sujeito de volta (nostalgia neurótica do paraíso perdido) à completude. Voltolini (2011) afirma que a sedução consiste em um retorno a um campo eminentemente materno, já que a sedutora originária é a mãe, na medida em que ela introduz a criança ao prazer, ao jogo de olhar e de captação. O que conduz, inevitavelmente, a um convite em direção à não distinção, isto é, à não separação. Por isso, “(...) o pai da horda - o velho Orango, como o disse Lacan — não era pai, de modo algum, mas mãe incestuosa embebida em seu próprio gozo. Na origem, radicalmente falando, não há função paterna” (ENDO, 2011, p. 69).

A sedução realizada pelo capitalismo incide no sujeito via mãe toda gozante, na medida em que o sujeito não apenas goza com o objeto, mas é capturado por ele. Em sua lógica de sedução, o capitalismo conduz a uma paralisia do desejo, na medida em que não há espaço para a falta, apenas para o consumo.

Nesse contexto, Hannah Arendt (2013) aponta a necessidade de cultura como a principal diferença entre a sociedade e a sociedade de massas, ambas consideradas pela filósofa política como fazendo parte da época moderna. A sociedade, anterior à sociedade de massas, valorizava e desvalorizava objetos culturais ao transformá-los em mercadorias, usava e abusava deles, mas não os consumia. Esses objetos, mesmo quando gastos por esses usos e abusos, permaneciam sendo objetos, mantinham sempre um caráter objetivo de modo que não desapareciam.

Entretanto, na sociedade de massas, os objetos não são objetos culturais, mas objetos para entretenimento e são consumidos pela sociedade como quaisquer outros bens de consumo, servindo, dessa forma, ao processo vital da sociedade, “(...) ainda que possam não ser tão necessários para sua vida como o pão e a carne" (ARENDT, 2013, p. 257). Os produtos necessários à diversão servem para passar o tempo que sobrou depois do tempo do trabalho e do sono. Mas eles não produzem efetivamente um hiato no ciclo do trabalho condicionado biologicamente, hiato efetivamente proporcionado pela cultura, mas uma repetição do mesmo tempo vital do trabalho.

Segundo a filósofa,

Sob as condições modernas, (...) há cada vez mais tempo livre (...), mas esse enorme acréscimo no tempo vago não altera a natureza do tempo. O divertimento, assim como o trabalho e o sono, constitui, irrevogavelmente, parte do processo vital biológico. E a vida biológica constitui sempre, (...) um metabolismo que se alimenta das coisas devorando-as. (ARENDT, 2013, p. 258) 
Para Hannah Arendt, o problema da sociedade de massas é que tal sociedade não fabrica um mundo por ficar restrita ao processo vital consumidor das pessoas que o habitam. Assim, o problema é ela ser essencialmente uma sociedade de consumo e, dessa forma, ter a atitude de consumo como atitude central ante todos os objetos, condenando à ruína tudo em que toca, pois devora os objetos e não instaura um tempo para além do tempo do processo vital. É nesse sentido que ela afirma que “(...) a sociedade de massas, onde o homem como animal social reina supremo e onde aparentemente a sobrevivência da espécie poderia ser garantida em escala mundial, pode ao mesmo tempo ameaçar de extinção a humanidade" (ARENDT, 2014, p. 56).

Assim, não surpreende que o mal-estar e o desamparo que fingimos exorcizar através da religião, da ciência e do capitalismo retornem, de maneira fulminante no campo das relações sociais e afetivas, sob a forma de sofrimento. De modo que encontramos um panorama sombrio: "O assassinato do sujeito e a substituição do desejo pelo gozo são as condições para o Império dos Sentidos. Lá, os seres falantes são classificados pelo usufruto dos objetos: famosos, uniclass, vip, top, personalité, cliente especial etc." (FERREIRA, 2010, p. 431).

Como sabemos, o assassinato de que se trata é o do sujeito do desejo, na medida em que o mesmo fica capturado por uma estrutura de discurso na qual o consumo ordena a dimensão do sacrifício no nosso tempo (COSTA, 2011). Sacrifício implicado em cada nova necessidade, em cada nova dependência, o que conduz o sujeito a uma nova forma de gozo, revelando a dupla vertente do mal-estar na cultura antecipado por Freud: “(...) o sujeito não apenas sofre ao se ver impedido de gozar irrestritamente de seus bens em favor da cultura. Seu mal-estar maior reside no próprio consumo dos bens trazidos pela cultura” (BERNARDES, 2007, p. 142).

Desta forma, os discursos da religião, da ciência e do capitalismo ao produzirem a massificação dos sujeitos através da oferta de um sentido, um saber e um objeto padrão colocados como medida comum para o gozo acabam excluindo, não apenas a singularidade do sujeito, mas, cada vez mais, suas chances inventivas diante do desamparo e do mal-estar, condições estruturais e estruturantes da vida e da condição humana.

Recebido em: 9 de novembro de 2015. Aprovado em: 8 de abril de 2016. 


\section{REFERÊNCIASS}

ARENDT, H. Entre o passado e o futuro. São Paulo: Perspectiva, 2013.

A condição humana. Rio de Janeiro: Forense Universitária, 2014.

ASKOFARÉ, S. A religião, a ciência e a psicanálise. Percurso. N. 43. 2009. Disponível em:<http://revistapercurso.uol.com.br/index.php?apg=artigo_ view\&ida $=4 \& i d \_t e m a=48>$. Acesso em: 21 out 2015 .

BERNARDES, W. S. A ciência e a religião. Epistemo-Somática. V. IV, n. 01. 2007. Disponível em: <http://pepsic.bvsalud.org/pdf/epistemo/v4n1/ v4n1a13.pdf>. Acesso em: 21 out 2015.

CLAVREUL, J. A ordem médica - poder e impotência do discurso médico. São Paulo: Brasiliense, 1983.

COSTA, A. M. M. da. Classificação e medida comum de gozo. In: JERUSALINSKY, A.; FENDRIK, S. (orgs.) O livro negro da psicopatologia contemporânea. São Paulo: Via Lettera, 2011.

COSTA PEREIRA, M. E. Pânico e desamparo: um estudo psicanalítico. São Paulo: Escuta, 2008.

ENDO, P. C. Um futuro sem origem: transmissão, autoridade e violência. Autoridade e violência. Porto Alegre: APPOA, 2011.

DESCARTES, R. Discurso do método. São Paulo: Martins Fontes, 1996.

DI CIACCIA, A. Tutti i sintomiportano a Roma. Intervenção nas Jornadas da Escola da Causa Freudiana, nos dias 5 e 6 nov 2005. Disponível em: $<$ http://www.opcaolacaniana.com.br/antigos/noticias1.htm>. Acesso em: 21 out 2015.

FERREIRA, N. P. Algumas reflexões sobre a contemporaneidade. Trivium, ano II, edição II. 2010. Disponível em: <http://www.uva.br/trivium/ edicoes/edicao-ii-ano-ii/artigos-tematicos/4-algumas-reflexoes-sobre-a-contemporaneidade.pdf>. Acesso em: 21 out 2015.

FREUD, S. Conferência XXXV - A questão de uma Weltanschauung (1933). Rio de Janeiro: Imago, 1980. (Ed. standard brasileira das obras completas, 22).

O futuro de uma ilusão (1927). Rio de Janeiro: Imago, 1980.

(Ed. standard brasileira das obras completas, 21).

O mal-estar na civilização (1930). Rio de Janeiro: Imago, 1980.

(Ed. standard brasileira das obras completas, 21).

Totem e tabu (1913). Rio de Janeiro: Imago, 1980. (Ed. standard brasileira das obras completas, 13).

HAUG, W. F. Crítica da estética da mercadoria. São Paulo: Fundação Editora da UNESP, 1997.

LACAN, J.A ciência e a verdade (1966). In: Escritos. Rio de Janeiro: J. Zahar, 1998.

As formações do inconsciente (1957-1958). Rio de Janeiro: J. Zahar, 1999. (O seminário, 5).

Introdução teórica às funções da psicanálise em criminologia (1950). In: Escritos. Rio de Janeiro: J. Zahar, 1998

O avesso da psicanálise (1969-1970). Rio de Janeiro: J. Zahar, 1992.

(O seminário, 17). 
O estádio do espelho como formador da função eu tal como nos é revelada na experiência psicanalítica (1949). In: _—. Escritos. Rio de Janeiro: J. Zahar, 1998.

O eu na teoria de Freud e na técnica da psicanálise (1954-1955). Rio de Janeiro: J. Zahar, 1985. (O seminário, 2).

Os quatro conceitos fundamentais da psicanálise (1964). Rio de Janeiro:

J. Zahar, 1985. (O seminário, 11).

O triunfo da religião precedido de Discurso aos católicos (19601974). Rio de Janeiro: J. Zahar, 2005.

LAPEYRE, M.; SAURET, M-J. A psicanálise com a ciência. Tempo Psicanalítico. V. 40, n. 2. 2008. Disponível em: <http://www.spid.com.br/ revistas/r40.2/04\%20TP40.2\%20-\%20Michel\%20Lapeyre.pdf>. Acesso em: 21 out 2015.

MARCON, H. H. A subjetividade no trabalho com saúde mental. Psychê: Revista de Psicanálise. V.11, n. 20, p. 151-164. São Paulo: Unimarco, 2007. REBOLLO, M. No princípio era o verbo. DiaLogos - Boletim do Ágora Instituto Lacaniano. N. 03. 2010. Disponível em: <http://pt.scribd. com/doc/135377735/PSICANALISE-E-RELIGIAO-pdf\#scribd>. Acesso em: 21 out 2015.

REINO, L. M. G.; ENDO, P. C. Três versões do narcisismo das pequenas diferenças em Freud. Trivium. Ano III, ed. II. 2011. Disponível em: <http:// www.uva.br/trivium/edicoes/edicao-ii-ano-iii/artigos-tematicos/tres-versoes-do-narcisismo-das-pequenas-diferencas-em-freud.pdf $>$. Acesso em: 21 out 2015.

ROUDINESCO, E. Por que a psicanálise? Rio de Janeiro: Zahar, 2000.

SZPIRKO, J. Psicoanalisis y Medicina. In: PURA, H. C.; DELLARIVA, C. (orgs.). La Clinique Psychanalytique au fil rouge de la science - Essais. Rosario: Homo Sapiens, 1995.

VALLEJO, A.; MAGALHÃES, L. C. Lacan: operadores da leitura. São Paulo: Perspectiva, 1981.

VOLTOLINI, R. Autoridade, violência e sedução. Autoridade e violência. Porto Alegre: APPOA, 2011.

Heloisa Helena Marcon

heloisamarcon@yahoo.com.br 